\title{
Healthy by Design: an innovative planning tool for the development of safe, accessible and attractive environments
}

\author{
Emma Sutherland $^{\mathrm{A}}$ and Rachel Carlisle C,C $^{\mathrm{B}, \mathrm{C}}$ \\ ${ }^{\mathrm{A} C o n s u l t a n t}$ \\ BNational Heart Foundation of Australia \\ ${ }^{\mathrm{C} C o r r e s p o n d i n g ~ a u t h o r . ~ E m a i l: ~}$ \\ rachel.carlisle@heartfoundation.org.au
}

\begin{abstract}
The Healthy by Design guidelines were developed by the National Heart Foundation of Australia in 2004 to assist planners to deliver plans for residential developments that support active living. This article provides an overview of the contents of this resource. It also provides examples of its application and influence in the planning sector.
\end{abstract}

Healthy by Design: a planners'guide to environments for active living (Healthy by Design) ${ }^{1}$ was released by the National Heart Foundation of Australia (Heart Foundation) in 2004. The guide is one of the more recent resources produced to build upon the Supportive Environments for Physical Activity work which commenced in Victoria in 1998. It followed initial research and development by the Heart Foundation in South Australia in $1996^{2}$ and $1999 .{ }^{3}$ Healthy by Design aims to demonstrate ways in which planners can influence the health and well-being of communities through their urban planning and design practice. The development of Healthy by Design was assisted by key stakeholders representing the planning, recreation, health, transport and community building sectors, with support from VicHealth and the Planning Institute Australia - Victoria Division.

Healthy by Design presents design considerations that facilitate 'healthy planning', resulting in healthy places for people to live, work and visit. 'Healthy urban planning' is about planning for people. It puts the needs of people and communities at the heart of the urban planning process and encourages decision-making based on human health and well-being. ${ }^{4}$ Since its release, the Heart Foundation has concentrated efforts on disseminating Healthy by Design to local and state government planners, private planners and planning consultants, developers, urban designers, engineers, landscape architects, land surveyors, health planners and relevant community organisations.

Two series of workshops for local government planners were held in 2004 and 2005 to provide them with a grounding in the principles that inform Healthy by Design and to demonstrate practical applications using local government case studies. Some limited interim evaluation has been undertaken, which has assisted in guiding the Heart Foundation's future directions for Healthy by Design.

By investing efforts in a 'supportive environments' approach to physical activity, the built environment will have better capacity to sustain people who choose to walk or cycle as part of their daily routine.

\section{Response to a planning need}

The Heart Foundation developed Healthy by Design to assist local government and associated planners in the implementation of a broader set of Supportive Environments for Physical Activity (SEPA) guidelines. The concept arose in response to feedback from local government planners and engineers who requested practical guidance in designing walkable communities. The original SEPA resource SEPA Guidelines for Local Government ${ }^{3}$ provided planners with an introductory framework to the built environment and physical activity. However, after two pilot projects were conducted with local governments, it was clear that more detailed direction was required to assist planners in the process of incorporating 'health' into their planning. When approaching the design of parks, re-vitalising local areas and adding new bike paths, planners were seeking more specific guidance to make the process of implementation easier.

In addition to this, the Planning for Health Benchmark Survey addressing planners' views, conducted by the Planning Institute Australia - Victoria Division, revealed that the majority of respondents (89\%) thought they had a role in creating a healthier, more physically active community; however, 49\% said they infrequently or never considered health issues in their daily planning work. ${ }^{5}$

There is an increasing trend toward physical inactivity. Data from the 2000 National Physical Activity Survey show that about $54 \%$ of Australians aged 18-75 years were 
not undertaking leisure-time physical activity at the levels recommended to obtain a health benefit, including $15 \%$ who reported no physical activity at all. ${ }^{6}$ Mortality figures show that more than 8000 deaths per year are associated with physical inactivity. In addition over seven million adult Australians are now considered overweight or obese. ${ }^{7}$

There are many ways to address this trend and the associated health impacts. One solution is designing environments that support the community being active as part of everyday life, such as providing for walkers and cyclists of all ages. The Heart Foundation therefore encourages planners and decision makers to be creative in their design of new urban developments and use budgets allocated for development or renewal of urban environments in ways that result in positive outcomes for public health.

Urban designs, such as mixed land uses, that increase the ability for people to walk or cycle to shops, schools, parks, services, facilities and public transport are more likely to increase physical activity and create more socially vibrant communities. This in return delivers a range of health, social, economic and environmental benefits. ${ }^{8}$

\section{Design considerations}

Healthy by Design provides planners with: supporting research; a range of design considerations to promote walking, cycling and public transport use; a practical design tool; and case studies.

The 'design considerations' demonstrate ways planners can improve the health of communities through their planning and design. This is encouraged by providing:

- well-planned networks of walking and cycling routes,

- streets with direct, safe and convenient access,

- local destinations within walking distance from homes,

- accessible open spaces for recreation and leisure,

- conveniently located public transport stops,

- well designed supporting infrastructure such as seating, signage, lighting, fencing and walls, and

- local neighbourhoods fostering community spirit. ${ }^{1}$

Table 1. Outline of design objectives and considerations presented in Healthy by Design: a planner's guide to environments for active living

\begin{tabular}{|c|c|c|}
\hline Aspect & Objective & Design considerations (outline) \\
\hline $\begin{array}{l}\text { Walking and } \\
\text { cycling routes }\end{array}$ & $\begin{array}{l}\text { To provide an accessible, integrated } \\
\text { network of walking and cycling routes } \\
\text { for safe and convenient travel to local } \\
\text { destinations and points of interest. }\end{array}$ & $\begin{array}{l}\text { - Make connections } \\
\text { - Create safe places for people to walk and cycle } \\
\text { - Create stimulating and attractive routes } \\
\text { - Design safe, accessible footpaths } \\
\text { - Shared path design }\end{array}$ \\
\hline Streets & $\begin{array}{l}\text { To design street networks that provide } \\
\text { direct, safe and convenient pedestrian } \\
\text { and cycle access. To position pedestrian } \\
\text { crossings along streets and roads with } \\
\text { heavy traffic volumes. }\end{array}$ & $\begin{array}{l}\text { - Slow traffic for safe streets } \\
\text { - Provide safe places to cross streets } \\
\text { - Support on-road cyclists } \\
\text { - Keep routes clear, direct and easy to navigate } \\
\text { - Create attractive and welcoming streets }\end{array}$ \\
\hline $\begin{array}{l}\text { Local } \\
\text { destinations }\end{array}$ & $\begin{array}{l}\text { To provide local destinations to support } \\
\text { lively, walkable and rideable } \\
\text { neighbourhoods. }\end{array}$ & $\begin{array}{l}\text { - Support mixed use, walkable neighbourhoods } \\
\text { - Provide a community 'heart' } \\
\text { - Support pedestrian access to local destinations } \\
\text { - Provide amenities for comfort and convenience }\end{array}$ \\
\hline Open space & $\begin{array}{l}\text { To provide a range of public open spaces } \\
\text { within walking distance from dwellings. } \\
\text { To clearly define walking and cycling } \\
\text { routes that pass through open spaces } \\
\text { and incorporate these routes into the } \\
\text { broader walking and cycling network. }\end{array}$ & $\begin{array}{l}\text { - Provide open spaces within safe, comfortable walking distances } \\
\text { - Connect to the broader walking and cycling network } \\
\text { - Encourage active recreation } \\
\text { - Create pleasing places to be } \\
\text { - Promote safety and amenity } \\
\text { - Provide for comfort and convenience }\end{array}$ \\
\hline $\begin{array}{l}\text { Public } \\
\text { transport }\end{array}$ & $\begin{array}{l}\text { To establish and promote clear and direct } \\
\text { walking and cycling routes to public } \\
\text { transport stops, and appealing and } \\
\text { convenient facilities for users. }\end{array}$ & $\begin{array}{l}\text { - Make public transport an easy option } \\
\text { - Provide safe, visible stops } \\
\text { - Provide facilities for comfort and convenience }\end{array}$ \\
\hline $\begin{array}{l}\text { Supporting } \\
\text { infrastructure }\end{array}$ & $\begin{array}{l}\text { To provide supporting infrastructure } \\
\text { that enables the safe and comfortable } \\
\text { use of pathways and streets by all } \\
\text { pedestrians and cyclists. }\end{array}$ & $\begin{array}{l}\text { - Address provision of seating and lighting to create } \\
\text { comfortable walking distances and provide security at night } \\
\text { - Provide clear navigational signage for walkers and cyclists } \\
\text { - Ensure fencing and walls enable clear connection and sight lines } \\
\text { between private property and the public realm }\end{array}$ \\
\hline $\begin{array}{l}\text { Fostering } \\
\text { community } \\
\text { spirit }\end{array}$ & $\begin{array}{l}\text { To develop built environment and } \\
\text { community participation strategies that } \\
\text { foster active communities and a sense of } \\
\text { community spirit. }\end{array}$ & $\begin{array}{l}\text { - Involve the community in planning activities } \\
\text { - Create spaces for community activity }\end{array}$ \\
\hline
\end{tabular}


Table 1 provides a brief summary of the design prompts covered in each of the above sections. Design considerations detailed in the guide suggest optimal design approaches to encourage active living. The design considerations may be used in a variety of settings to:

- prepare plans (e.g. open space master plans),

- design proposed developments,

- develop design guidelines or checklists,

- develop innovative built environment projects,

- assess development proposals,

- influence strategic directions,

- embed 'health' into Municipal Strategic Statements,

- influence planning scheme provisions, and

- contribute to the ongoing development and enhancement of open spaces.

Planners are required to consider a range of guidelines that affect health, safety and access, often in isolation from each other. Healthy by Design features 'Design for Safe \& Healthy Communities: the Matrix of Like Design Considerations'. ${ }^{1}$ This matrix is a tool that demonstrates the synergies between the different guidelines that influence built environment design, all of which contribute to positive health outcomes.

\section{Key achievements and outcomes}

Since its release, evaluations have demonstrated that local governments, planning bodies and community organisations have been utilising Healthy by Design in a variety of ways.

Examples of local government use are listed below.

- The interim Healthy by Design evaluation (via dissemination workshops) indicated that $95 \%$ of participants said the guide would 'definitely' $(63 \%)$ or 'probably' (32\%) enhance their current or future work activities. ${ }^{9}$

- A follow-up review of workshop participants revealed that Healthy by Design is being used as a reference document in most councils surveyed and as a policy platform in a small number of others. ${ }^{10}$

- The collection of case studies has revealed that local councils' use of the resource has evolved. For instance the Macedon Ranges Shire has produced Designing in Health and Wellbeing: Guidelines for Residential Subdivisions in the Macedon Ranges, and the City of Port Phillip has developed its Walk Plan 2005-2007 utilising the Healthy by Design concepts.

In addition, the adoption of Healthy by Design is growing.

- A leading Victorian property developer has utilised the guide in the development of a 'Sustainability Charter', having direct bearing on delivery benchmarks for each of their projects.

- Healthy by Design was recommended by the Victorian State Department of Human Services as a key source of information for their Public Health Research Project Funding 2004-2005 and in particular for 'built environment and health' research submissions, forming a key resource for new projects in the area of walking and the built environment.

- The guide has been acknowledged in many reports and plans, including the Inquiry into Sustainable Urban Design for New Communities in Outer Suburban Areas ${ }^{11}$ and Age-friendly built environments: Opportunities for local government. ${ }^{12}$

Following the development of Healthy by Design, a local neighbourhood audit tool has been developed titled Healthy Urban Environments: Site Assessment Audit. ${ }^{13}$ This is a complementary tool available for planners or community organisations wishing to assess the walkability of local areas. This tool was developed in conjunction with VicHealth, The Cancer Council Victoria and the Planning Institute Australia - Victorian Division.

\section{Conclusion}

Healthy by Design continues to gain momentum with local council planners. In the long term, plans reviewed by local governments that have utilised the Healthy by Design approach should result in an urban environment conducive to good health and ultimately contribute to measurable health outcomes.

As Trevor Budge, past President of the Planning Institute of Australia - Victoria division, commented, "The Healthy by Design guide... covers all of the aspects that will enable planners and subdivision engineers to plan healthy and cost-effective communities. It is a... major contribution to integrated planning and will enhance sustainable outcomes." 14

Healthy by Design demonstrates that when planning and health are integrated, the outcome is not only well planned neighbourhoods, but also neighbourhoods that positively influence health, wellbeing and the overall quality of community life.

\section{References}

1. National Heart Foundation of Australia (Victorian Division). Healthy by design: a planners' guide to environments for active living. Melbourne: National Heart Foundation of Australia (Victorian Division), 2004.

2. Wright C, MacDougall C, Atkinson R, Booth B. Exercise in daily life, supportive environments. report of a national heart foundation research project funded by the Commonwealth Department of Health and Family Services. Canberra: Commonwealth of Australia, 1996.

3. National Heart Foundation of Australia (SA Division). Supportive environments for physical activity: guidelines for local government. Adelaide: National Heart Foundation of Australia, 1999. 
4. Barton $\mathrm{H}$, Tsourou C. Healthy urban planning: a WHO guide to planning for people. Geneva: World Health Organization, 2000 .

5. Foos N, Maddern C. Planning for Health Benchmark Survey: an evaluation of planner awareness of health issues.

Melbourne: Planning Institute Australia - Victorian Division, 2002.

6. Australian Institute of Health and Welfare (AIHW). Physical inactivity. At http://www.aihw.gov.au/riskfactors/inactivity.cfm, accessed 21 September 2006.

7. AIHW and National Heart Foundation of Australia. Heart, stroke and vascular diseases - Australian facts 2004. Cardiovascular Disease Series No. 22, AIHW Cat. No. CVD 27, Canberra: AIHW and National Heart Foundation of Australia, 2004.

8. Frank L, Kavage S, Litman T. Promoting public health through smart growth. Report prepared for SmartGrowthBC, 2006.

9. National Heart Foundation of Australia (Victorian Division) \& Cancer Council Victoria's SunSmart Program. Healthy urban environments workshop evaluation report. Unpublished report prepared for VicHealth, 2004.
10. Kurth N. Healthy by Design (healthy urban environments) Victorian local government impact assessment. Unpublished report prepared by ASR Research Pty Ltd for the National Heart Foundation of Australia (Victorian Division), 2006.

11. Outer Suburban/Interface Services Development Committee, Inquiry into sustainable urban design for new communities in outer suburban areas: final report. Melbourne: Parliament of Victoria, 2004.

12. Australian Local Government Association. Age-friendly built environments: opportunities for local government. Canberra: Australian Local Government Association, 2005.

13. National Heart Foundation of Australia (Victorian Division). Healthy urban environments: site assessment audit.

Melbourne: National Heart Foundation of Australia (Victorian Division), 2006.

14. Budge T. Awards for Planning Excellence. Awards Citation. Melbourne: Planning Institute Australia - Victorian Division, 2004. 